\title{
Mantids (Mantodea) of Navsari Agricultural University campus (Gujarat): An Inventory
}

\author{
H.N. Patel ${ }^{1^{*}}$, A.G. Shukla ${ }^{2}$, A.H. Patel $^{3}$ and J.N. Prajapati ${ }^{4}$ \\ ${ }^{1}$ Department of Agricultural Entomology, N.M.C.A, NAU, Navsari, India \\ ${ }^{2}$ Acarologist AINP on Agricultural Acarology, Department of Agricultural Entomology, \\ N.M.C.A, NAU, Navsari, India \\ 3 Department of Agricultural Entomology, N.M.C.A, NAU, Navsari, india
}

*Corresponding author

\section{A B S T R A C T}

\section{Keywords}

Mantids, Predator,

Praying mantis, mantodea, Navsari, Gujarat, India

Article Info

Accepted:

25 May 2018

Available Online:

10 June 2018
The main aims of the present study were documentation of species, habitats and other ecological behaviors of Mantids in district Navsari, Gujarat, India during August 2016 July 2017. Total 21 species of mantids belongs to 15 genera, from five families were recorded from different localities of NAU campus. Among them 21 species were belongs to five families viz., Mantidae (12), Hymenopodidae (2), Liturgusidae (1) Empusidae (3) and Toxoderidae (3). In general, the mantids were active in all kind of habitat including pond ecosystem, paddy ecosystem, grassland ecosystem, mango ecosystem and banana ecosystem. Considering the abundance of mantids total 21 species recorded in present study viz. Mantis religiosa (Burmeister, 1838) Hierodula viridis (Burmeister, 1838), Humbertiella ceylonica (Saussure, 1869), Archimantis latistyla (Serville, 1838), Hierodula venosa (Oliver,1792), Aethalochroa ashmoliana (West-wood, 1841), Statilia maculata (Zheng,1987), Schizocephala bicornis (Linnaeus,1758), Hierodula membranacea (Burmeister,1838), Tenodora sinensis (Nurseryman, 1962), Hierodula keraleness (Vyjayandi, 1995), Creobroter apicalis (West-wood, 1889), Hierodula coarctata (Saussure, 1869), Empusa guttula (Thunberg, 1815), Hierodula grandis (Saussure, 1869), Aethalochroa insignis (Wood-Mason, 1878), Toxoderopsis spinigera (Wood-Mason, 1889), Ameles fasciipennis (Kaltenbach, 1963), Gongylus gongylodes (Linnaeus, 1758), Gongylus trachelophyllus (Burmeister, 1838) and Tropiodo guttatipennies (Stal, 1877).

\section{Introduction}

Mantids (Insecta: Mantodea), usually known as Praying Mantis, hold significant place in the ecosystem as predators, mainly feed on grasshoppers, moths, butterflies, flies, aphids and they are well adapted in camouflage and mimicry (1). Mantids have attained their common popular name from the way they raise their two fore legs in a posture of prayer. They are often found waiting still for hours together for their prey with their heads rotating $180^{\circ}(2)$. They are diurnal and are attracted to lights at night (3). They are weak flies and are generally seen sitting on herbs, shrubs and trees (4). There are around 2300 
species of mantids under 434 genera all over the world (5). There are 162 species of mantids under 68 genera of six families in India (6). Research on mantids in India was further propelled by several researchers in India (7- 12). 4 species and 4 genera of mantids have so far been recorded from all over Gujarat (6). There being no Mantids fauna from the Navsari district in particular, the present study aims at making a Mantid inventory though recording Mantid species from the district.

In the face of rapid decline of all organism and habitats owing to fast urbanisation and industrialisation in this district, a list of Mantid fauna is extremely necessary to observe change in their biodiversity. We are representing here mantids diversity of NAU campus. Due to important ecosystem services of mantids and rapid habitat degradation, it is very important to study about the mantids diversity of this district along with their distribution and abundance.

\section{Materials and Methods}

\section{Study area}

Navsari Agricultural University, main campus, Navsari is situated at $20^{\circ} 57^{\prime}$ North Latitude and $72^{\circ} 54^{\prime}$ East Longitude and at an altitude of 10 meter above the Mean Sea Level (MSL). The Navsari Agricultural University, campus is located $12 \mathrm{~km}$ away in the east from the Arabian seashore, Dandi a historical place well known for "Salt Satyagraha" of Mahatma Gandhi, the father of Nation. The area under study covers 333.42 hectares (excluding roads, buildings, residential colonies and offices) of land under varying uses of agricultural, horticultural and plantation purpose and barren land in the Navsari Agricultural University, Navsari main campus, in the Navsari district of Gujarat state.

\section{Methods}

Adult, free flying mantids was collected from the above localities using standard insect collecting swap net attached to a ring with a handle of $1.00 \mathrm{~m}$ length, $0.3 \mathrm{~m}$ hoop ring diameter. The soft nylon net with $1.00 \mathrm{~m}$ depth sewed on the hoof ring. Collections are made from the different type of ecosystem like; agricultural fields, weedy ponds, small ponds, agro- forestry, fruit trees, vegetable fields, etc. Mostly, spot observation was followed by collection and photography from the different areas for their identification. Generally photographic documentation was done. Photographs were taken using (Sony Alpha a7S gigital camera) with $18-55 \mathrm{~mm}$ lens. "Identification of Mantid species was done with the help of these authentic literatures $(1,5,6)$ and by Mantid expert Dr. H. V. Ghate, Professor of Zoology, Modern College, Pune-411001, Maharashtra, India. After noting characteristics identification record the live dragonflies were preserved through dry method of preservation for entomological museum.

\section{Data analysis}

Data analyses were performed by PAST software Version 3.02 (13).

\section{a. Measurement of diversity}

The type of diversity used here is $\alpha$ - diversity which is the diversity of species within a community or habitat. The diversity index was calculated by using the diversity index (14).

Diversity index $=\mathrm{H}=-\Sigma \mathrm{Pi}$ In $\mathrm{Pi}$, where $\mathrm{Pi}=$ $\mathrm{S} / \mathrm{N}$

$\mathrm{S}=$ number of individuals of one species

$\mathrm{N}=$ total number of all individuals in the sample

In = natural logarithm 


\section{b. Measurement of species richness}

Margalef's index was used as a simple measure of species richness (15).

Margalef's index $=(\mathrm{S}-1) / \mathrm{In} \mathrm{N}$

$\mathrm{S}=$ total number of species

$\mathrm{N}=$ total number of individuals in the sample

In = natural logarithm

\section{c. Dominance and Simpson index}

$\mathrm{D}=\Sigma(\mathrm{ni} / \mathrm{n}) 2$ where $\mathrm{ni}$ is number of individuals of taxon $\mathrm{i}$.

Dominance $=1$-Simpson index. Ranges from 0 (all taxa are equally present) to 1 (one taxon dominates the community completely).

Simpson index 1-D. Measures 'evenness' of the community from 0 to 1 . Dominance and Simpson indices are often used interchangeably.

\section{Results and Discussion}

During the present study, total 21 species of mantids were recorded from different locations, which belong to five families. Among them 57.14 per cent species belongs to family Mantidae, 14.28 per cent from Empusidae, 14.28 per cent species belongs to family Toxoderidae, 9.52 per cent species represents Hymenopodidae, and remaining 4.76 per cent species from family Liturgusidae (Table 1). In a study also reported a total 10 species of mantids belonging to 9 genera under 3 families viz. Mantidae, Hymenopodidae and Liturgusidae (16). The Mantidae was the most dominant family. Under the present study Mantidae was the most dominant family comprises of 8 genera and 12 species with 57.14 per cent species distribution. This may be more or less in accordance with the earlier work. Further, reported Mantidae as one of the most dominant family (17), therefore closely support the present findings.
Total 374 mantids were collected from various agro ecosystems of Navsari Agricultural University campus during August 2016 to July 2017. Looking to species wise distribution the results showed that Mantis religiosa (Burmeister, 1838) (67.37), was found the most abundant in the study area followed by Hierodula viridis (Burmeister, 1838) (6.95), and Humbertiella ceylonica (Saussure, 1869) $(5.34 \%)$, which were also recorded as very common species.

Whereas, Archimantis latistyla (Serville, 1838) (2.40\%), Hierodula venosa (Oliver, 1792) (2.13\%), Aethalochroa ashmoliana (West-wood, 1841) (1.87\%), Statilia maculata (Zheng, 1987) $(1.60 \%)$, were evidenced as common in occurrence. Similarly, 15 species viz. Schizocephala bicornis (Linnaeus, 1758) (1.60\%), Hierodula membranacea (Burmeister,1838) (1.60\%), Tenodora sinensis (Nurseryman, 1962) (1.06\%), Hierodula keraleness (Vyjayandi, 1995) (1.06\%), Creobroter apicalis (West-wood, 1889) $(0.80 \%)$, Hierodula coarctata (Saussure, 1869) (0.80\%), Empusa guttula (Thunberg, 1815) $(0.80 \%)$, Hierodula grandis (Saussure, 1869) $(0.80 \%)$, Aethalochroa insignis (WoodMason, 1878) (0.80\%), Toxoderopsis spinigera (Wood-Mason, 1889) (0.80\%), Ameles fasciipennis (Kaltenbach, 1963) $(0.53 \%)$, Gongylus gongylodes (Linnaeus, 1758) (0.53\%), Gongylus trachelophyllus (Burmeister, 1838) (0.53\%), Tropiodo guttatipennies (Stal, 1877) (0.53\%) were found as rarely occurred Mantids under the present study area. Further, reported $M$. religiosa, $H$. viridis and $H$. keralensis as the most dominant species in Kerala (12), thus more or less in accordance with the present findings. In a survey, (17) also reported Mantidae as a most dominant family followed by Hymenopodidae and Liturguridae, this findings closely support the present study. 
Table.1 Species distribution of mantids in different families

\begin{tabular}{|r|l|c|c|c|}
\hline & \multicolumn{1}{|c|}{ Family } & Genera & No. of species & \% Species \\
\cline { 2 - 5 } & Mantidae & 8 & 12 & 57.14 \\
\cline { 2 - 5 } Order & Hymenopodidae & 2 & 2 & 9.52 \\
\cline { 2 - 6 } MANTODEA & Liturgusidae & 1 & 1 & 4.76 \\
\cline { 2 - 6 } & Empusidae & 2 & 3 & 14.28 \\
\cline { 2 - 6 } & Toxoderidae & 2 & 3 & 14.28 \\
\hline Total & $\mathbf{5}$ & $\mathbf{1 5}$ & $\mathbf{2 1}$ & $\mathbf{1 0 0}$ \\
\hline
\end{tabular}

Table.2 Population and abundance of mantids in South Gujarat

\begin{tabular}{|c|c|c|c|}
\hline $\begin{array}{l}\text { Sr. } \\
\text { No. }\end{array}$ & Mantid Species & $\begin{array}{l}\text { Population } \\
\text { (No) }\end{array}$ & $\begin{array}{c}\text { Abundance } \\
(\%)\end{array}$ \\
\hline 1. & Ameles fasciipennis (Kaltenbach, 1963) & 2 & 0.53 \\
\hline 2. & Humbertiella ceylonica (Saussure, 1869) & 20 & 5.34 \\
\hline 3. & Gongylus gongylodes (Linnaeus,1758) & 2 & 0.53 \\
\hline 4. & Tenodora sinensis (Nurseryman, 1962) & 4 & 1.06 \\
\hline 5. & Mantis religiosa (Burmeister, 1838) & 252 & 67.37 \\
\hline 6. & Hierodula viridis (Burmeister, 1838) & 26 & 6.95 \\
\hline 7. & Creobroter apicalis (Westwood, 1889) & 3 & 0.80 \\
\hline 8. & Hierodula keraleness (Vyjayandi, 1995) & 4 & 1.06 \\
\hline 9. & Aethalochroa ashmoliana (Westwood, 1841) & 7 & 1.87 \\
\hline 10. & Statilia maculata (Zheng, 1987) & 6 & 1.60 \\
\hline 11. & Hierodula coarctata (Saussure, 1869) & 3 & 0.80 \\
\hline 12. & Empusa guttula (Thunberg, 1815) & 3 & 0.80 \\
\hline 13. & Gongylus trachelophyllus (Burmeister, 1838) & 2 & 0.53 \\
\hline 14. & Archimantis latistyla (Serville, 1838) & 9 & 2.40 \\
\hline 15. & Hierodula grandis (Saussure, 1869) & 3 & 0.80 \\
\hline 16. & Tropiodo guttatipennis (Stal, 1877) & 2 & 0.53 \\
\hline 17. & Hierodula membranacea (Burmeister, 1838) & 6 & 1.60 \\
\hline 18. & Schizocephala bicornis (Linnaeus, 1758) & 6 & 1.60 \\
\hline 19. & Aethalochroa insignis (Wood-Mason, 1878) & 3 & 0.80 \\
\hline 20. & Hierodula venosa (Olivier, 1792) & 8 & 2.13 \\
\hline 21. & Toxoderopsis spinigera (Wood-Mason, 1889) & 3 & 0.80 \\
\hline \multicolumn{2}{|r|}{ Total } & 374 & 100 \\
\hline
\end{tabular}

Table.3 Measurements of diversity related indices

\begin{tabular}{|c|l|c|}
\hline Sr. No. & Diversity related indices & Calculated results \\
\hline $\mathbf{1}$ & Taxa_S & 21 \\
\hline $\mathbf{2}$ & Shannon_H & 1.49 \\
\hline $\mathbf{3}$ & Evenness_e^ $\mathrm{A} / \mathrm{s}$ & 0.49 \\
\hline $\mathbf{4}$ & Margalef & 7.78 \\
\hline
\end{tabular}


Present finding showed the huge diversity of mantids from Navsari Agricultural University campus. So, The value of species richness (Taxa_S), Diversity index (Shannon_H), Evenness_ $\mathrm{e}^{\wedge} \mathrm{H} / \mathrm{s}$ and Margalef's index were $21,1.49,0.49$ and 7.78 , respectively. The present findings were closely supported by (18).

In conclusion, the mantids were active in all kind of habitat including pond ecosystem, paddy ecosystem, grassland ecosystem, mango ecosystem and banana ecosystem. Considering the abundance of mantids total 21 species recorded in present study viz. Mantis religiosa (Burmeister, 1838), Hierodula viridis (Burmeister, 1838), Humbertiella ceylonica (Saussure, 1869), Archimantis latistyla (Serville, 1838), Hierodula venosa (Oliver,1792), Aethalochroa ashmoliana (West-wood, 1841), Statilia maculate (Zheng,1987), Schizocephala bicornis (Linnaeus, 1758), Hierodula membranacea (Burmeister,1838), Tenodora sinensis (Nurseryman, 1962), Hierodula keraleness (Vyjayandi, 1995), Creobroter apicalis (West-wood, 1889), Hierodula coarctata (Saussure, 1869), Empusa guttula (Thunberg, 1815), Hierodula grandis (Saussure, 1869), Aethalochroa insignis (Wood-Mason, 1878), Toxoderopsis spinigera (Wood-Mason, 1889), Ameles fasciipennis (Kaltenbach, 1963), Gongylus gongylode (Linnaeus, 1758), Gongylus trachelophyllus (Burmeister, 1838) and Tropiodo guttatipennies (Stal, 1877).

\section{Acknowledgement}

The authors are thankful to Dr. H. V. Ghate, Professor of Zoology, Modern College, Pune411001, Maharashtra, India for identification of Mantids, also thankful to Professor and Head, Department of Entomology, N. M. College of Agriculture, Navsari, The Principal and Dean, N. M. College of agriculture,
Navsari and Director of Research and Dean P.G. Studies for providing all the necessary facilities during the course of study.

\section{References}

1. Sureshan PM, Sambath S. Mantid (Insecta: Mantodea) fauna of old Bihar (Bihar and Jharkhand) with some new records for the state. Records of the Zoological Survey of India. 2009; 109(3):11-26.

2. Sureshan PM. A Preliminary Study on the Mantid Fauna (Insecta: Mantodea) of Orissa, India. Rec. zool. Surv. India. 2009; 305:1-56.

3. Dutta W, Sur D. Preying Mantis: A threatened group of insect from Purulia, West Bengal. Biodiversity Conservation: Fundamentals and Applications. 2012; 262-263.

4. Sathe TV, Vaishali PJ. Report on nine new species of mantids (Insecta: Mantodea) and their insect pest predatory potential from agroecosystems of Kolhapur region, Journal of Entomology and Zoology Studies. 2014; 2(5):304-307.

5.Ehrmanm $\mathrm{R}$. Mantodea: Gottesanbeterinnen der Welt. Naturund Tier-Veriag GombH (NTV), Munster, Germany. 2002; 519.

6. Mukherjee TK, Hazra AK, Ghosh AK. The mantid fauna of India (Insecta: Mantodea). Oriental Insects. 1995; 29:185-358.

7. Ghate HV, Ranade SP. Biodiversity of mantids (Insecta: Mantodea) in Pune (Western Ghats) with notes on other regions of Maharashtra, J Bombay Nat. Hist. Soc. 2002; 99(2):348-352.

8. Rao TK, Ghate HV, Sudhakar M, Maqsood JSM, Krishna SR. Updated checklist of praying mantid species (Insecta: Mantodea) from Nagarjunasagar Srisailam Tiger Reserve, Andhra 
Pradesh. Zoos' Print Journal. 2005; 20(6):1905-1907.

9. Sureshan PM, Jafer P, Radhakrishnan C. New additions to the mantid fauna (Insecta: Mantodea) of Andaman and Nicobar Islands, India. Zoos' Print Journal. 2004; 19(7):1544.

10. Sureshan PM, Ghate HV, Radhakrishnan C. Insecta: Mantodea. Fauna of Tadoba Andhari tiger Reserve. Zoo1. Surv. India. Conservation Area Series. 2006; 25:227-232.

11. Vyjayandi MC, Narendran TC, Mukherjee TK. A new species of praying mantis (Insecta: Mantodea) from Kerala, India. Oriental Insects. 2006; 40:285290.

12. Vyjayandi MC. Mantid fauna of Kerala, India. Rec. zoo1. Surv. India. Occ. 2007; 267:1-169.

13. Hammer $\varnothing$, Harper DAT, Ryan PD. PAST: Paleontological Statistics Software Package for Education and Data Analysis. Palaeontologia Electronica. 2001; 4(1):9.
14. Shannon CE, Wiener W. The mathematical theory of communication. Urbana, University of Illinois Press. 1949, 177.

15. Margalef R. Temporal succession and spatial heterogeneity in phytoplankton. In: Perspectives in Marine biology, Buzzati-Traverso (ed.), Univ. Calif. Press, Berkeley. 1958, 323-347.

16. Dwari, S. and Mondal, A. K. Diversity of mantids (Insecta: Mantodea) of Howrah district, West Bengal, India. Journal of Entomology and Zoology Studies, 2018; 6(2):1038-1042.

17. Rivera, J. and Cobián, C. V. A checklist of the praying mantises of Peru: new records, one new genus (Piscomantis gen. n.) and biogeographic remarks (Insecta, Mantodea). Zootaxa, 2017; 4337(3):361-389.

18. Helmkampf, M. E., Schwarz, C. J. and Beck, J. A first look at the biodiversity of praying mantids. (Insecta: Mantodea) in Sabah, Borneo. Sepilok Bulletin, 2007; 7:1-13.

\section{How to cite this article:}

Patel, H.N., A.G. Shukla, A.H. Patel and Prajapati, J.N. 2018. Mantids (Mantodea) of Navsari Agricultural University campus (Gujarat): An Inventory. Int.J.Curr.Microbiol.App.Sci. 7(06): 3594-3599. doi: https://doi.org/10.20546/ijcmas.2018.706.423 